\title{
Bone Substitutes Used in Guided Bone Regeneration Tedmique Review
}

\author{
EUGENAPOPESCU, DORIANAAGOP FORNA', KAMEL EARAR?, NORINACONSUELAFORNA? \\ ${ }^{1}$ University of Medicine and Pharmacy Grigore T.Popa, Faculty of Dental Medicine, Iasi, Romania 16 Independentei Str., 700115, \\ Iasi, Romania \\ 2Dunarea de J os University, Faculty of Medicine and Pharmacy, 47 Domenasca Str., 800008, Galati, Romania
}

\begin{abstract}
This paper aims to synthesize the main categories of biomaterials (bone substitutes, collagen membranes) used in the reconstruction of oral bone defects and alveolar augmentation by guided bone regeneration technique. The review of literature data shows that guided bone regeneration technique offers reliable and predictable results in the implant-prosthetic treatments.
\end{abstract}

Keywords: guided bone regeneration, biomaterials, bone substitutes, collagen membranes

The demand for complex oral rehabilitation has significantly increased in the late decade due to the high esthetic demands of patients. Another factor is related to the production of new biomaterials and the introduction of more effective new biotechnologies with direct clinical applications in prosthetic oral rehabilitation (sinus lift, alveolar augmentation, rehabilitation of intraosseous defects and peri-implant defects) [1]. As the implant mechanical stability ensures the successful osteointegration, long-term successful dental-implantsupported bridges require high volume and normal density bone support [2]. The post-extraction crestal bone resorption is associated to $40-60 \%$ loss of bone height and width respectively within 2 to 3 years [3]. These data explains the popularity of Guided Bone Regeneration (GBR) technique in modern dentistry. GBR is a surgical procedure that uses barrier membranes with or without bone grafts or/and bone substitutes. [4]. In GBR the choice of bone grafting material is related to variables as follows: patients' systemic healing capacity, the osteogenic potential of the recipient site, and the time available for graft maturation [5]. When a barrier membrane is placed in direct contact with the surrounding bone surface and bone defect, only stem cells capable of osteogenic differentiation can migrate into the bone defect, allowing the further bone formation withoutcompetition from the epithelial cells and fibroblasts from the overlying mucosa [6]. GBR and bone artificial substitutes are especially used to restore both the continuity of dental alveolar arches and the functions of the stomatognathic system in partially extensive edentulous [7]. GBR has a major importance in the preoperative stage of implant surgery considering the high failure rates of dental implants when associated to poor bone quality [8]. The grafted implant sites allow larger implants placement and require less augmentation procedures at the moment of implant placement when compared to naturally healed sites [9].

Table 1 present the categories of bone graft materials, commercial brands, sources, composition, properties

The bone substitutes are divided in four categories, accordingly to source and origin: autogenous grafts, allografts, xenografts and alloplasts [4].

Autogenous grafts (bone transferred from one area to another area within the same patient) is harvested from iliac crest, mandibular ramus or calvarial bone. The action mechanism consists in the formation of new bone by osteogenesis (in the absence of undifferentiated stem cells), osteoinduction (transformation of undifferentiated stem cells in osteoblasts), and osteoconduction (provides a physical matrix that encourages the deposition of new bone from the surrounding bone or encourage the deposition of the differentiated mesenchymal cells on the graft surface) [26]. Due to all these actions, autogenous grafts are the gold standard in the bone reconstruction [4]. However some limitations represented by the necessity of harvesting from a secondary surgical site with possible patient morbidity, the difficulty of obtaining a sufficient amount of graft material, led to the search of new bone substitutes [4].

Bone allografts are block bone grafts harvested from one individual and used to another individual of the same species [4]. Allografts have only osteoconductive and osteoinductive properties. This graft category has some advantages over autogenous grafts (avoiding of donor procedure from another site, high bone volume supply and some disadvantages (longer bone formation, less bone regeneration) [4].

Xenografts and alloplasts have only osteoconductive properties [26]. Xenografts are tissue grafts obtained from a species other than the host species. [4]. Xenograft are used as scaffold for new bone formation. The most used xenograft materials are based on natural hydroxyapatite and deorganified bovine bone. These graft materials are inert osteoconductive filler material, which serves as a scaffold for new bone formation. Xenografts have the risk of a host-immune response and easy migration [27].

Alloplasts are synthetic graft material. The alloplast materials are as follows: calcium carbonate, calcium sulfate, bioactive glass polymers and synthetic hydroxyapatite and tricalcium phosphate (TCP) [4]. The xenograft and alloplasts materials resorbs to a high percentage in the timeframe desired between extraction and dental implant placement, as shown clinically, radiographically, and histologically [25]. However the regenerated material in the socket has high density and support the implant placement.

Despite numerous studies aiming to investigate the survival rate of bone grafts, hes new researches will conduct to the accurate reproduction of the chemical parameters and morphological features of the natural bone as well as the correlation with biological behaviours and concepts [28]. 
In vivo studies can validate new bone substitute materials based on long-term outcomes and the monitorisation of peri-implantitis rate [29].

Table 1

BONE SUBSTITUTES USED IN GUIDED BONE REGENERATION

\begin{tabular}{|c|c|c|c|}
\hline $\begin{array}{l}\text { Material } \\
\text { category }\end{array}$ & $\begin{array}{l}\text { Commercial } \\
\text { products }\end{array}$ & Source/Composition & Properties \\
\hline Autogenous & & $\begin{array}{l}\text { Block bone grafts from anterior } \\
\text { and posterior iliac crest } \\
\text { Mandibular ramus } \\
\text { Calvarial bone grafts }\end{array}$ & $\begin{array}{c}\text { Gold standard }[4,10,11] \\
\text { High success rates }[4,10,11] \\
\text { The iliac crest has the highest concentration of } \\
\text { osteocompetent cells, offers sufficient volume, } \\
\text { readily accessible [12] } \\
\text { Calvarial bone grafts offers sufficient volume and } \\
\text { show less resorption comparing with iliac crest } \\
\text { grafts [13] } \\
\text { 19.37\% complications (infection, haematoma, } \\
\text { hypertrofic scar, fracture) following iliac crest bone } \\
\text { harvesting; only } 6 \% \text { complications following } \\
\text { harvesting of long bone intramedullary canal using } \\
\text { the RIA device[14] } \\
\text { Mandibular ramus bone grafts have low morbidity } \\
\text { but also low amount of available bone [15] }\end{array}$ \\
\hline Allografts & $\begin{array}{l}\text { Puros (Zimmer } \\
\text { Dental) }\end{array}$ & $\begin{array}{c}\text { Freeze-dried bone } \\
\text { demineralized freeze-dried bone } \\
\text { allograft } \\
\text { mineralized freeze-dried bone } \\
\text { allograft }\end{array}$ & $\begin{array}{l}\text { osteoinductive potential (still maintain vital cells), } \\
\text { low morbidity, discomfort, operation time }[16,17] \\
\text { minimal resorption, low failure rate }(2.4 \% \text { ) of } \\
\text { allogeneic bone block grafts following } 4-9 \text { months } \\
\text { post-treatment [18] } \\
\text { mean gain of } 4.79 \mathrm{~mm} \text { horizontal and } 2 \mathrm{~mm} \text { vertical } \\
\text { bone [19-21] }\end{array}$ \\
\hline Xenografts & $\begin{array}{c}\text { Bio-Oss } \\
\text { (Osteohealth) }\end{array}$ & animal origin & $\begin{array}{l}\text { Bio-Oss provides better bone quality and volume } \\
\text { when compared with alloplast graft (Nanobone) } \\
{[22]}\end{array}$ \\
\hline Alloplasts & $\begin{array}{l}\text { Nanobone } \\
\text { perossal (biotiss } \\
\text { dental) } \\
\text { Cerabone } \\
\text { (botiss dental) }\end{array}$ & $\begin{array}{l}\text { Hydroxyapatite (HA) } \\
\text { HA + calcium phosphate } \\
\text { beta-tricalciumphosphate } \\
\text { (B-TCP) }\end{array}$ & $\begin{array}{l}\text { xenograft bone substitute (hydroxyapatite) } \\
\text { associated with collagen membrane is an effective } \\
\text { technique that increases the bone quality and } \\
\text { implant success [23] } \\
\text { osteoconductive; allows proteins and growth } \\
\text { factors to bind directly to surface; volume and } \\
\text { mechanical stability } \\
\text { dimensionally stable, absence of immunological } \\
\text { reactions } \\
\text { absence of bone loss in } 72.1 \% \text { implants) [24] } \\
\text { no incidences of postoperative infection or graft } \\
\text { rejection; high density of the implant recipient } \\
\text { sites; the width of the extraction sockets was } \\
\text { preserved to } 91 \% \text { of the preoperative width [25] }\end{array}$ \\
\hline
\end{tabular}




\begin{tabular}{|c|l|l|l|}
\hline & $\begin{array}{l}\text { Maxresorb (botiss } \\
\text { dental) }\end{array}$ & $60 \% \mathrm{HA}+40 \% \mathrm{~B}-\mathrm{TCP}$ & $\begin{array}{l}\text { resorbable, safe, osteoconductive; maintains } \\
\text { volume and mechanical graft stability }\end{array}$ \\
\hline $\begin{array}{c}\text { Composite } \\
\text { grafts }\end{array}$ & & & $\begin{array}{l}\text { autogenous+xenografts is a predictible technique in } \\
\text { severe atrophic maxillary anterior ridges [18] }\end{array}$ \\
\hline
\end{tabular}

\section{References}

1.BARTOK FF, FORNA N. Peri-implantitis - a review of actual treatment methods. Romanian Journal of Oral Rehabilitation 2016, Vol. 8, No. 3:5-11.

2.J AVEED F, AHMED HB, CRESPI R, ROMANOS GE. Role of primary stability for successful osseointegration of dental implants: Factors of influence and evaluation. Interv Med Appl Sci. 2013 Dec; 5(4):162167.

3.ASHMAN A. Ridge preservation: important buzzwords in dentistry. Gen Dent. 2000; 48(3):304-12.

4.LIU J, KERNS DG. Mechanisms of Guided Bone Regeneration: A Review. Open Dent J. 2014; 8: 56-65.

5.WANG HL, CARROLL MJ. Guided bone regeneration using bone grafts and collagen membranes. Quintessence Int. 2001 Jul-Aug; 32(7):504-15.

6.BUNYARATAVEJ P, WANG HL. Collagen membranes: a review. J Periodontol. 2001 Feb; 72(2):215-29.

7. FORNA N (coordonator), DE BAAT C, BRATU D, LASCU L, MERCUT V, PETRE AL, POPSOR S, TRAISTARU T. Protetica Dentara, vol.II, Edit.Enciclopedicã, Bucure-ti, 2011.

8. BECKTOR JP, ECKERT SE, ISAKSSON S, KELLER EE. The influence of mandibular dentition on implant failures in bone-grafted edentulous maxillae. Int J Oral Maxillofac Implants. 2002 Jan-Feb;17(1):69-77. 9.BARONE A, ORLANDO B, CINGANO L, MARCONCINI S, DERCHI G, COVANI U. A randomized clinical trial to evaluate and compare implants placed in augmented versus non-augmented extraction sockets: 3-year results. J Periodontol. 2012 J ul;83(7):836-46.

10.NKENKE E, NEUKAM FW. Autogenous bone harvesting and grafting in advanced jaw resorption: morbidity, resorption and implant survival. Eur J Oral Implantol. 2014; 7:203-17.

11.STERN A, BARZANI G. Autogenous bone harvest for implant reconstruction. Dent Clin North Am. 2015 Apr;59(2):409-20

12. BARONE A, RICCI M, MANGANO F, COVANI U. Morbidity associated with iliac crestharvesting in the treatment of maxillary and mandibular atrophies: a 10-year analysis. J Oral Maxillofac Surg. 2011 Sep; 69(9):2298304.

13. MERTENS C, DECKER C, SEEBERGER R, HOFFMANN J , SANDER A, FREIER K. Early bone resorption after vertical bone augmentationa comparison of calvarial and iliac grafts. Clin Oral Implants Res. 2013 Jul; 24(7):820-5.

14. DIMITRIOU R, MATALIOTAKIS GI, ANGOULES AG, KANAKARIS NK, GIANNOUDIS PV. Complications following autologous bone graft harvesting from the iliac crest and using the RIA: a systematic review. Injury. 2011 Sep; 42 Suppl 2:S3-15.

15. MONJE A, PIKOS MA, CHAN HL, SUAREZ F, GARGALLO-ALBIOL J, HERNÁNDEZ-ALFARO F, GALINDO-MORENO P, WANG HL. On the feasibility of utilizing allogeneic bone blocks for atrophic maxillary augmentation. Biomed Res Int. 2014;2014:81.

16. DALLARI D., FINI M., STAGNI C., TORRICELLI P., ALDINI N. N., GIAVARESI G., CENNI E., BALDINI N., CENACCHI A., BASSI A., GIARDINO R., FORNASARI P. M., GIUNTI A. In vivo study on the healing of bone defects treated with bone marrow stromal cells, platelet-rich plasma, and freeze-dried bone allografts, alone and in combination. Journal of Orthopaedic Research. 2006;24(5):877-888

17.SIMPSON D., KAKARALA G., HAMPSON K., STEELE N., ASHTON B. Viable cells survive in fresh frozen human bone allografts. Acta Orthopaedica. 2007;78(1):26-30.

18.MONJE A, MONJE F, HERNANDEZ-ALFARO F, GONZALEZ-GARCIA R, SUAREZ LOPEZ DEL AMO F, GALINDO-MORENO P, MONTANEROFERNANDEZ J, WANG HL. Horizontal Bone Augmentation Using Autogenous Block Grafts and Particulate Xenograft in the Severe Atrophic Maxillary Anterior Ridges: A Cone-Beam Computerized Tomography Case Series.J Oral Implantol. 2015 Jul; 41:366-71.

19. NISSAN J., MARDINGER O., CALDERON S., ROMANOS G. E., CHAUSHU G. Cancellous bone block allografts for the augmentation of the anterior atrophic maxilla. Clinical Implant Dentistry and Related Research. 2011;13(2):104-111.

20.WALLACE S., GELLIN R. Clinical evaluation of freeze-dried cancellous block allografts for ridge augmentation and implant placement in the Maxilla.Implant Dentistry.2010;19(4):272-279.

21. ACOCELLA A., BERTOLAI R., ELLIS E., III, NISSAN J., SACCO R. Maxillary alveolar ridge reconstruction with monocortical fresh-frozen bone blocks: A clinical, histological and histomorphometric study. J ournal of Cranio-Maxillofacial Surgery. 2012;40(6):525-533

22.SHAKIBAIE-M B. Comparison of the effectiveness of two different bone substitute materials for socket preservation after tooth extraction: a controlled clinical study. J Periodontics Restorative Dent. 2013 Mar-Apr; 33(2):223-8.

23.CAVDAR FH, KECELI HG, HATIPOGLU H, DEMIRALP B, CAGLAYAN F. Evaluation of Extraction Site Dimensions and Density Using Computed Tomography Treated With Different Graft Materials: A Preliminary Study.Implant Dent. 2017;26(2):270-274.

24. HAREL N, MOSES O, PALTI A, ORMIANER Z. Long-term results of implants immediately placed into extraction sockets grafted with âtricalcium phosphate: a retrospective study.J Oral Maxillofac Surg. 2013 Feb; 71(2):e63-8

25. HOROWITZ RA, MAZOR Z, MILLER RJ, KRAUSER J, PRASAD HS, ROHRER MD. Clinical evaluation alveolar ridge preservation with a beta-tricalcium phosphate socket graft. Compend Contin Educ Dent. 2009 Nov-Dec; 30(9):588-90, 592, 594 passim; quiz 604, 606.

26. MISCH CE, DIETSH F. Bone-grafting materials in implant dentistry. Implant Dent 1993; 2: 158-67.

27.LANE J M. Bone graft substitutes. West J Med 1995; 163: 565-6.

28. SUL YT, KANG BS, J OHANSSON C, UM HS, PARK C], ALBREKTSSON $\mathrm{T}$. The roles of surface chemistry and topography in the strength and rate of osseointegration of titanium implants in bone. Journal of Biomedical Materials Research: Part A. 2009;89(4):942-950.

29. EHRENFEST DM, WANG HL, BERNARD JP, SAMMARTINO G. New biomaterials and regenerative medicine strategies in periodontology, oral surgery, esthetic and implant dentistry. BioMed Research International. 2015; Vol.2015: 1-3.

$\overline{\text { Manuscript received: } 11.12 .2016}$ 